あった。問\} MTCのアンプリチュードが Sinc $120 \mathrm{~V} \cdot$ Gaussian $70 \mathrm{~V}$ と高值なので SAR にかからない

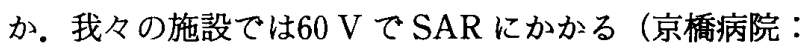

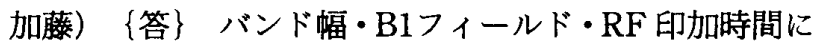
よって異なるが当院ではSARにかからない。

【8,9,10】 3 演者は MTC と傾斜プロファイル RF と の併用が最も末梢血管抽出能が優れていたとの報告であ った.

【RF 強度について】 MTC 用 RF の強度を表すのに 印加電圧 $(\mathrm{V})$ で報告するのが慣例となっているが，表示 印加電圧はメーカ・装置固有の値であり絶対值ではない。 本来可能であれば RF の強度は電力（W）で表すのが望 ましい様に思う。また患者への熱効果について考えると， オンレゾナンスかオフレゾナンスかに依っても異なり， オフレゾナンスの RF を用いる場合, MTC 効果を得る のに強い $\mathrm{RF}$ 強度が必要であるが反面熱効果は少ない。

今回の傾斜プロファイル RF を用いた報告で，使用装 置は 2 社に限られた。本法は頭部 MRA において現在で は不可欠な方法であり，励起用 RF の変更だけでハード の特別な変更もなく行える為, 各メーカの早急な対応を 期待したい。また近年へリカルスキャンCT の登場によ り，CT による頭部血管造影も臨床に十分役立つ画像を 迅速に提供出来るように成ってきた，今後の MRA との 動向が興味深い.

\section{CT 臨床応用（胸部）（演題番号11～15）}

花井耕造（国立がんセンター） 本演題群では高速 CT スキャンの臨床応用の中で, 特 に胸部疾患への応用に関する研究報告が多くなされた。 以下に本演題群で行われた質疑応答について述べる。

（質問） 国立がんセンター：村松．表面線量測定に際 する, TLD の配置方法と測定回数は. 線量の SD が少な すぎると考える，ラセン状 CT では表面線量は回転周期 に比例して波打つために SD は大きくなる.

（答）茨城県立中央病院：上原. 両側乳房の中間点に 体軸方向に 2 力所, 配置した. 測定回数は 5 回. 回転に 伴う表面線量の変動は考慮していない.

（質問）座長. 寝台移動速度の選択方法の基準は何か. （答） 揖斐病院：今村. 患者の様態により選択する.

（質問）長野赤十字病院：八町. 造影刻濃度-1500使 用経験の有無は．造影剂濃度を薄くし，注入圧と量を高 めることでインジェクターの誤差が除去できないか.

（答）富山医科薬科大病院：伊藤. 造影剤濃度を変え ることは考慮していない.
（質問） 東邦大学：新木. 肺野病変において早期造影 相を必要性とするその根拠は何か。

（答） 伊藤：縌隔内病変およびリンパ節の鑑別を主た る目的とする場合に，䋛隔内血管の早期造影相のみ十分 である。静脈相は必要としない。これにより造影剂の総 量を隇らすことができる。

（質問）座長：肺野 1 次検診に扔ける線量の下限は.

（答） 村山：肺尖部において50 mA ではノイズの問 題点が発生する。本実験では $100 \mathrm{~mA}$ を最低線量とした。 今後, 低線量スキャンについても考察して行きたい.

（質問） 聖マリアンナ病院：鈴木。一次検診から CT を利用できないか。

（答）処理人数の立場から 1 次検診の位置付けはでき ない.

その他，大同病院：上谷氏より集団検診を想定した場 合の処理可能人数。およびX線管側蓄積熱容量からの制 約の有無についての質問がなされた。

本演題の主たる内容である胸部領域の高速 CT の応用 に関しては，今後，社会的要請として，特に1（集団）, 2 次検診を念頭に, 被曝とスキャン条件, 造影剤使用量 などの多方面からの研究と議論が要求される。これらの 問題点に対して，明快な答えを提供して行くことこそが 本学会の責務の 1 つと考える。

\section{CT 臨床応用（腹部）（演題番号16～19）}

新木 操（東邦大学医学部付属大橋病院） この演題群は腹部 CT 領域における螺旋状スキャン方 式の臨床応用及び従来型スキャン方式の造影手技に関す る研究発表計 4 題が行われた。

演題16，17は同一演者によるマルチスキャンの検討が 報告され，DPR 法と TPS 法について，その有用性を撮 影条件の面から検討し報告された。

最近の腹部領域に扔ける螺旋状スキャンを用いた撮影 は，質的診断を目的とした他に，3D や MIP などの画像 処理を目的とした撮影も同時に行われるようになり，ス ライス厚は薄く，撮影時間は長くなる傾向にある，患者 の被曝を考えると，その適応を良く考えて実施する必要 がある（質疑応答）福井医大 東村よりスライス厚と テーブル移動速度の関係で SD 值が理論と異なるという 質問があり，関連して札幌麻布 宮下より補間法によっ て異なるため使用補間法についての質問があったが，こ こで表示した SD 值はノイズを問題とした SD 値でなく 表面線量の SD 值であるため演者らの報告で良いと思わ れる. 後に質問者からも訂正があった。補間法は180度補 